\title{
FAKTOR RISIKO YANG BERHUBUNGAN DENGAN KEJADIAN KEKURANGAN ENERGI KRONIK (KEK) IBU HAMIL DI WILAYAH KERJA PUSKESMAS NAMBO KOTA KENDARI
}

\author{
Vira Patmalia ${ }^{1}$ Lymbran Tina ${ }^{2}$ Akifah $^{3}$ \\ 1,2,3Fakultas Kesehatan Masyarakat Universitas Halu Oleo Kendari \\ 1vbyraapatmaliaa@gmail.com²Lymbranizzah@gmail.comªkifahf@gmail.com
}

\begin{abstract}
Abstrak
Kekurangan energi kronik (KEK) merupakan keadaan dimana ibu menderita keadaan kekurangan kalori dan protein (malnutrisi) yang berlangsung menahun (kronis) yang mengakibatkan timbulnya gangguan kesehatan pada ibu hamil.penelitian ini bertujuan untuk mengetahui hubungan antara pola konsumsi, pantang makan, pengetahuan ibu, penyakit infeksi pada ibu hamil di wilayah kerja puskesmas nambo kota kendari. Metode penelitian ini adalah observasional analitik pendekatan case control study. Teknik pengambilan sampel dalam penelitian ini adalah dengan menggunakan simple random sampling. Sampel penelitian ini berjumlah 64 sampel yakni 32 kasus dan 32 kontrol di lakukan sejak juli-agustus 2020. Hasil penelitian pada tingkat kepercayaan 95\% menunjukkan faktor risiko kejadian KEK dengan pola konsumsi pada ibu hamil di peroleh nilai $\mathrm{p}=0,021$ dengan nilai OR $=3,400$ (CI 95\% 1,1799,808) dan pantang makan di peroleh nilai $\mathrm{p}=0,044$ dengan nilai $\mathrm{OR}=0,044$ (CI 95\% 1,017-7,869) dan pengetahuan ibu di peroleh nilai $\mathrm{p}=0,012$ dengan nlai $\mathrm{OR}=3,667$ (CI 95\% 1,303-10,321) sedangkan yang bukan merupakan faktor risiko kejadian KEK Yakni penyakit infeksi di peroleh nilai $\mathrm{p}=0,012$ dengan nilai OR $=3,207$ (CI 95\% 0,315-32,604). Ibu hamil diharapkan lebih memperhatikan kesehatan dirinya selama kehamilannya.
\end{abstract}

Kata Kunci : $\quad$ Kekurangan energi kronik (KEK); Faktor Risiko

\begin{abstract}
Chronic energy deficiency (KEK) is a condition in which the mother suffers from a chronic shortage of calories and protein (malnutrition) which results in health problems in pregnant women. This study aims to determine the relationship between consumption patterns, abstinence from food, maternal knowledge, Infectious diseases in pregnant women in the working area of Puskesmas Nambo, Kendari City. This research method is analytic observational with a case control study approach. The sampling technique in this study was to use simple random sampling. The research sample consisted of 64 samples, 32 cases and 32 controls carried out since July-August 2020. The results of the study at the $95 \%$ confidence level showed the risk factors for KEK incidence with consumption patterns in pregnant women obtained a value of $\mathrm{p}=0.021$ with an OR $=3,400$ ( $95 \%$ CI 1.179-9.808) and abstinence from food were obtained $\mathrm{p}$ value $=0.044$ with $\mathrm{OR}=0.044$ (95\% CI 1.017-7.869) and maternal knowledge obtained $\mathrm{p}$ value $=0.012$ with $\mathrm{OR}=3.667$ (95\% CI 1.303-10.321) while those who are not risk factors for the incidence of KEK are infectious diseases obtained by $\mathrm{p}$ value $=0.012$ with OR $=3.207$ (95\% CI 0.315 32.604). Pregnant women are expected to pay more attention to their health during pregnancy.
\end{abstract}

Keywords : Pregnancy chronic energy deficiency (KEK); risk Factors

\section{PENDAHULUAN}

Kekurangan Energi Kronik (KEK) merupakan keadaan dimana ibu menderita keadaan kekurangan kalori dan protein (malnutrisi) yang berlangsung menahun (kronis) yang mengakibatkan timbulnya gangguan kesehatan pada ibu hamil. Seorang ibu yang mengalami KEK diukur dengan pita LILA. Pengukuran LILA kurang dari $23,5 \mathrm{~cm}$ atau dibagian merah pita LILA maka ibu menderita KEK, jika LILA ibu sama dengan atau lebih dari $23,5 \mathrm{~cm}$ maka tidak beresiko menderita KEK (Demsa, 2018). ${ }^{1}$

Menurut Word Health Organization (WHO) jumlah ibu hamil yang mengalami kekurangan energi kronik pada tahun 2016 sebanyak (30,1\%). Pada tahun 2017 jumlah ibu hamil yang mengalami kekurangan energi kronik secara global sebanyak (35-75\%). Kejadian kekurangan energi kronik di negara-negara berkembang seperti Baghladesh, India, Indonesia, Myanmar, Nepal, Srilanka dan Thailand adalah (15$47 \%$ ) yaitu dengan BMI < 18,5. Adapun negara yang mengalami kejadian yang tertinggi adalah Bangladesh yaitu $(47 \%)$, sedangkan Indonesia menjadi urutan keempat terbesar setelah India dengan kejadian (35,5\%) dan yang paling rendah adalah Thailand dengan kejadian(15-25\%) (Fatimah, 2019). ${ }^{2}$

Berdasarkan RISKESDAS 2018 proporsi resiko KEK pada ibu hamil terdapat 5 provinsi dengan proporsi tertinggi yaitu Nusa Tenggara Timur (NTT), Maluku, Maluku Utara, Sulawesi Tenggara, dan Papua. Proporsi tertinggi yaitu Provinsi NTT dengan 36,8 \%, 
proporsi terendah ialah Provinsi Kalimantan Utara dengan $1,7 \%$, dan rata-rata Indonesia yaitu $17,3 \%$. (Kementerian Kesehatan RI, 2018). Sedangkan Sulawesi Tenggara memiliki proporsi resiko KEK pada ibu hamil sebesar $28 \%$ yang tentunya berada di atas rata-rata proporsi dari keseluruhan Provinsi di Indonesia, lebih tepatnya peringkat ke empat dengan proporsi tertinggi. (Kementerian Kesehatan RI, 2018). ${ }^{3}$

Penyebab utama kejadian KEK Pada ibu hamil yaitu sejak sebelum hamil sudah mengalami kekurangan energi karena kebutuhan orang hamil lebih tinggi dari ibu dalam keadaan hamil. Kehamilan menyebabkan meningkatnya metabolisme energi, karena itu kebutuhan energy dan zat gizi lainnya meningkat selama hamil. Menurut Sediaoetama (2014), penyebab dari KEK dapat dibagi menjadi dua, yaitu penyebab langsung dan tidak langsung. Penyebab langsung terdiri dari asupan makanan atau pola konsumsi dan infeksi. Adapun penyebab tidak langsung terdiri dari a) hambatan utilitas zat-zat gizi, b) hambatan absorbsi karena penyakit infeksi atau infeksi cacing, c) ekonomi yang kurang, d) pengetahuan, e) pendidikan umum dan pendidikan gizi kurang, f) produksi pangan yang kurang mencukupi kebutuhan, g) kondisi bygiene yang kurang baik, h) jumlah anak yang terlalu banyak, i) hamil usia dini, j) penghasilan rendah, k) perdagangan dan distribusi yang tidak lancar dan tidak merata, i) pola makan yang kurang baik. Penyebab tidak langsung dari KEK disebut juga penyakit dengancausa multi factorial dan antara hubungan menggambarkan interaksiantara faktor dan menuju titik pusat kekurangan energi kronis (Sediaoetama, 2014).

Berdasarkan data wilayah Sulawesi Tenggara, Kota Kendari mengalami kenaikan proporsi KEK pada ibu hamil dalam tiga tahun terakhir yaitu 9,91\% pada tahun 2016, 10,75\% pada tahun 2017, dan 11,11\% pada tahun 2018 (Dinas Kesehatan Provinsi Sulawesi Tenggara, 2019). Berdasarkan laporan tahunan Dinas Kesehatan Kota Kendari dari 15 puskesmas yang berada di wilayah Kota Knedari, Prevalensi paling tertinggi kejadian Kekurangan Energi Kronik (KEK) terdapat pada Puskesmas Nambo sebanyak 91,0\% sedangkan kejadian Kekurangan Energi Kronis (KEK) paling terendah terdapat di wilayah Puskesmas Poasia sebayak 3,6\%. (Dinas Kesehatan Kota Kendari 2019). ${ }^{4}$

Berdasarkan latar belakang penulis tertarik untuk meneliti tentang faktor-faktor yang mempengaruhi Kejadian Kekurangan Energi Kronik (KEK) ibu hamil masyarakat pesisir di wilayah kerja puskesmas nambo kota kendari tahun $2020 .{ }^{5}$

\section{METODE}

Penelitian ini merupakan jenis penelitian kuantitatif dengan desain penelitian observasional analitik menggunakan pendakatan stdi kasus kontrol (case control study) untuk menganalisis faktror pola konsumsi, pantang makan, pengetahuan ibu, penyakit infeksi terhadapkejadian kekurangan energi kronik (KEK) ibu hamil di wiayahh kerja Puskesmas Nambo. Poplasi dalam penelitian ini yaitu seluruh ibu hamil di wilayah kerja Puskesmas Nambo . Sampel dalam penelitian ini berjumlah 64 yang terdiri dari 32 kasus dan 32 kontrol.

\section{HASIL}

a. Karakteristik Responden

Tabel 1. Distribusi Responden Menurut Usia Pada Ibu Hamil Di Wilayah Kerja Puskesmas Nambo Kota Kendari

\begin{tabular}{ccccccc}
$\begin{array}{c}\text { Umur } \\
\text { ibu hamil }\end{array}$ & \multicolumn{2}{c}{ Kasus } & kontrol & \multicolumn{2}{c}{ Total } \\
\cline { 2 - 7 } & $\mathbf{n}$ & $\mathbf{\%}$ & $\mathbf{n}$ & $\mathbf{0}$ & $\mathbf{N}$ & $\mathbf{\%}$ \\
\hline $15-20$ & 4 & 12,5 & 5 & 15,6 & 9 & 14,1 \\
\hline $21-25$ & 13 & 40,6 & 12 & 37,5 & 25 & 39,1 \\
\hline $26-30$ & 6 & 18,8 & 7 & 21,9 & 13 & 20,3 \\
\hline $31-45$ & 9 & 28,1 & 8 & 25,0 & 17 & 26,6 \\
\hline Total & $\mathbf{3 2}$ & $\mathbf{1 0 0}$ & $\mathbf{3 2}$ & $\mathbf{1 0 0}$ & $\mathbf{6 4}$ & $\mathbf{1 0 0}$ \\
Sumber $:$ Data Primer Diolah & Agustus 2020 & & &
\end{tabular}

Tabel 1 menunjukkan bahwa dari 32 responden $(100 \%)$ pada kelompok kasus, paling banyak responden berusia 21-25 tahun yaitu sebanyak 13 responden $(40,6 \%)$, sedangkan yang paling sedikit berusia 15-20 tatun yaitu sebanyak 9 responden $(14,1 \%)$. Dan distribusi responden pada kelompok kontrol dari 32 responden (100\%) lebih banyka kelompok berusia 21-25 tahun yaitu 12 responden (37,5\%), sedangkan yang paling sedikit berusia $15-20$ tahun yaitu sebanyak 5 responden (15,6\%).

Tabel 2. Distribusi Responden Menurut Usia Kehamilan Pada Ibu Hamil Di Wilayah Kerja Puskesmas Nambo Kota Kendari

\begin{tabular}{lcccccc}
\multirow{2}{*}{$\begin{array}{c}\text { Usia } \\
\text { Kehamilan }\end{array}$} & \multicolumn{2}{c}{ Kasus } & \multicolumn{2}{c}{ Kontrol } & \multicolumn{2}{c}{ Total } \\
\cline { 2 - 8 } & $\mathbf{n}$ & $\mathbf{0}$ & $\mathbf{n}$ & $\mathbf{\%}$ & $\mathbf{N}$ & $\mathbf{0}$ \\
\hline Trimester I & 2 & 6,2 & 1 & 3,1 & 3 & 4,7 \\
\hline Trimester II & 20 & 62,5 & 27 & 84,4 & 47 & 73,4 \\
\hline Trimester III & 10 & 31,2 & 4 & 12,5 & 14 & 21,9 \\
\hline Total & $\mathbf{3 2}$ & $\mathbf{1 0 0}$ & $\mathbf{3 2}$ & $\mathbf{1 0 0}$ & $\mathbf{6 4}$ & $\mathbf{1 0 0}$ \\
Sumber : data primer diolah Agustus 2020 & &
\end{tabular}

Tabel 2 menunjukkan bahwa dari 32 responden $(100 \%)$ pada kelompok kasus lebih banyak pada kelompok usia kehamilan trimester 2 dengan jumlah sebanyak 20 responden $(62,5 \%)$, sedangkan yang paling sedikit sebanyak 2 responden $(6,2 \%)$. Dan distribusi responden pada kelompok kontrol dari 32 responden $(100 \%)$ lebih banyak pada kelompok trimester 2 dengan jumlah sebanyak 27 responden $(84,4 \%)$ dan yang paling sedikit dengan jumlah sebanyak 1 responden $(3,1 \%)$.

Tabel 3 Distribusi Responden Menurut Pendidikan Responden Pada Ibu Hamil Di Wilayah Kerja Puskesmas Nambo Kota Kendari

\begin{tabular}{|c|c|c|c|c|c|c|}
\hline \multirow{2}{*}{ Pendidikan } & \multicolumn{2}{|c|}{ Kasus } & \multicolumn{2}{|c|}{ Kontrol } & \multicolumn{2}{|c|}{ Total } \\
\hline & $\mathbf{n}$ & $\%$ & $\mathbf{n}$ & $\%$ & $\mathbf{N}$ & $\%$ \\
\hline SD & 3 & 9,4 & 1 & 3,1 & 4 & 6,2 \\
\hline SMP & 10 & 31,2 & 4 & 12,5 & 14 & 21,9 \\
\hline SMA & 15 & 46,9 & 24 & 75,0 & 39 & 60,9 \\
\hline D3 & 1 & 3,1 & 1 & 3,1 & 2 & 3,1 \\
\hline S1 & 3 & 9,4 & 2 & 6,2 & 5 & 7,8 \\
\hline Total & 32 & 100 & 32 & 100 & 64 & 100 \\
\hline
\end{tabular}


Tabel 3 menunjukkan bahwa dari 32 responden (100\%) pada kelompok kasus yang paling banyak responden memiliki pendidikan terakhir tamatan SMA dengan jumlah sebanyak 15 responden (46,9\%), sedangkan yang paling sedikit D3 dengan jumlah sebanyak 1 responden $(3,1 \%)$. Dan responden pada kelompok kontrol dari 32 responden yang paling banyak terdapat pada pendidikan SMA dengan jumlah 24 responden $(75,0 \%)$ sedangkan yang paling sedikit yaitu SD dengan jumlah 1 responden $(3,1 \%)$ dan D3 dengan jumlah 1 responden $(3,1 \%)$.

Tabel 4. Distribusi Responden Meunurut Pekerjaan Responden Pada Ibu Hamil Di Wilayah Keja Puskesmas Nambo Kota Kendari

\begin{tabular}{ccccccc}
\multirow{2}{*}{ Pekerjaan } & \multicolumn{2}{c}{ Kasus } & \multicolumn{2}{c}{ Kontrol } & \multicolumn{2}{c}{ Total } \\
\cline { 2 - 7 } & $\mathbf{n}$ & $\mathbf{0}$ & $\mathbf{n}$ & $\mathbf{0}$ & $\mathbf{N}$ & $\mathbf{\%}$ \\
\hline IRT & 30 & 93,8 & 28 & 87,5 & 58 & 90,6 \\
\hline WIRASWASTA & 1 & 3,1 & 4 & 12,5 & 5 & 7,8 \\
\hline HONORER & 1 & 3,1 & 0 & 0 & 1 & 1,6 \\
\hline Total & $\mathbf{3 2}$ & $\mathbf{1 0 0}$ & $\mathbf{3 2}$ & $\mathbf{1 0 0}$ & $\mathbf{6 4}$ & $\mathbf{1 0 0}$
\end{tabular}

Sumber : data primer diolah Agustus 2020

Tabel 4 menunjukkan bahwa dari 32 responden (!00\%) pada kelompok kasus, distribusi pekerjaan responden lebih banyak sebagai ibu rumah tangga sebanyak 30 responden $(93,8 \%)$, sedangkan pada kelompok kontrol distribusi pekerjaan responden lebih banyak sebagai ibu rumah tangga sebanyak 28 responden $(87,5 \%)$, dan honorer tidak ada.

\section{b. Analisis Bivariat}

Tabel 5. Analisis Faktor Risiko pola konsumsi dengan Kekurangan energi kronik (KEK) Ibu hamil di Wilayah Keja Puskesmas Nambo Kota Kendari tahun 2020

\begin{tabular}{|c|c|c|c|c|c|c|c|}
\hline \multirow{3}{*}{$\begin{array}{c}\text { Pola } \\
\text { Konsumsi }\end{array}$} & \multicolumn{4}{|c|}{ Kejadian KEK } & \multirow{2}{*}{\multicolumn{2}{|c|}{ Total }} & \multirow{2}{*}{$\begin{array}{c}P \text {-Value } \\
(0.021)\end{array}$} \\
\hline & \multicolumn{2}{|c|}{ Kasus } & \multicolumn{2}{|c|}{ Kontrol } & & & \\
\hline & (n) & $(\%)$ & (n) & $(\%)$ & $\mathbf{N}$ & $\%$ & OR \\
\hline Kurang Baik & 15 & 46,9 & 24 & 75,0 & 39 & 60,9 & $(3.400)$ \\
\hline Baik & 17 & 53,1 & 8 & 25,0 & 25 & 39,1 & \\
\hline Total & 32 & 100 & 32 & 100 & 64 & 100 & $\begin{array}{l}(1,179- \\
9,808)\end{array}$ \\
\hline
\end{tabular}

Berdasarkan tabel 1 , dapat di ketahui bahwa dari 32 responden $(100 \%)$ pada kelompok kasus, terdapat 17 responden $(53,1 \%)$ yang memiliki pola konsumsi baik dan terdapat 15 responden $(46,9 \%)$ yang memiliki pola konsumsi kurang. Sedangkan kelompok kontrol terdapat 8 responden $(25,0 \%)$ yang memiliki pola konsumsi baik dan terdapat 24 responden $(75,0 \%)$ yang memiliki pola konsumsi kurang.

Hasil Analisis statistik dengan uji Chi-Square terkait pola konsumsi dengan kejadian Kekurangan Energi Kronik (KEK) pada ibu hamil pada Confidence Interval (CI) 95\% di peroleh dari OR yakni 3.400 dengan Lower Limit (Batas Bawah) adalah angka pada kolom yang letaknya disebelah kiri yakni 1.179 dan Upper Limit (Batas atas) adalah angka pada kolom yang letaknya disebelah kanan yakni 9.808. Intreprestasi nilai Lower
Limit dan Upper Limit tidak mencakup nilai satu maka Ho di tolak dan OR dinyatakan bermakna, sehingga dapat di nyatakan bahwa adanya hubungan antara pola konsumsi dengan kejadian Kekurangan Energi Kronik (KEK) sebanyak 3,4 kali lebih beresiko dengan pola konsumsi kurang dibandingkan dengan ibu hamil yang memiliki tingkat pola konsumsi baik

Tabel 6. Analisis Faktor Risiko Pantang makan dengan Kekurangan energi kronik (KEK) Ibu hamil di Wilayah Keja Puskesmas Nambo Kota Kendari tahun 2020

\begin{tabular}{|c|c|c|c|c|c|c|c|}
\hline \multirow{3}{*}{$\begin{array}{c}\text { Pantang } \\
\text { Makan }\end{array}$} & \multicolumn{4}{|c|}{ Kejadian KEK } & \multirow{2}{*}{\multicolumn{2}{|c|}{ Total }} & \multirow{2}{*}{$\begin{array}{c}\boldsymbol{P} \text { - } \\
\text { Value } \\
(0,044)\end{array}$} \\
\hline & \multicolumn{2}{|c|}{ Kasus } & \multicolumn{2}{|c|}{ Kontrol } & & & \\
\hline & (n) & $(\%)$ & (n) & $(\%)$ & $\mathbf{N}$ & $\%$ & OR \\
\hline Ada & 22 & 68,8 & 14 & 43,8 & 36 & 56,2 & $(2,829)$ \\
\hline Tidak Ada & 10 & 31,2 & 18 & 56,2 & 28 & 43,8 & $95 \% \mathrm{CI}$ \\
\hline Total & 32 & 100 & 32 & 100 & 64 & 100 & $\begin{array}{l}(1.017- \\
7.869)\end{array}$ \\
\hline
\end{tabular}

Berdasarkan tabel 2 , dapat di ketahui bahwa dari 32 responden $(100 \%)$ pada kelompok kasus, terdapat 22 responden $(68,8 \%)$ yang memiliki pantang makan dan terdapat 10 responden $(31,2 \%)$ yang tidak memiliki pantang makan. Sedangkan kelompok kontrol terdapat 14 responden $(43,8 \%)$ yang memiliki pantang makan dan terdapat 18 responden $(68,2 \%)$ yang tidak memiliki pantang makan tidak ada.

Hasil Analisis statistik dengan uji Chi-Square terkait pantang makan dengan kejadian Kekurangan Energi Kronik (KEK) pada ibu hamil pada Confidence Interval (CI) 95\% di peroleh dari OR yakni 2.829 dengan Lower Limit (Batas Bawah) adalah angka pada kolom yang letaknya disebelah kiri yakni 1.017 dan Upper Limit (Batas atas) adalah angka pada kolom yang letaknya disebelah kanan yakni 7.869. Intreprestasi nilai Lower Limit dan Upper Limit tidak mencakup nilai satu maka Ho di tolak dan OR dinyatakan bermakna, sehingga dapat di nyatakan bahwa adanya hubungan antara pantang makan dengan kejadian Kekurangan Energi Kronik (KEK) sebanyak 2,8 kali lebih beresiko dengan pantang makan idak ada dibandingkan dengan ibu hamil yang memiliki pantang makan ada.

Tabel 7. Analisis Faktor Risiko pengetahuan ibu dengan Kekurangan energi kronik (KEK) Ibu hamil di Wilayah Keja Puskesmas Nambo Kota Kendari

\begin{tabular}{|c|c|c|c|c|c|c|c|}
\hline \multirow{3}{*}{$\begin{array}{l}\text { Pengetahuan } \\
\text { Ibu }\end{array}$} & \multicolumn{4}{|c|}{ Kejadian KEK } & \multirow{2}{*}{\multicolumn{2}{|c|}{ Total }} & \multirow{2}{*}{$\begin{array}{c}\boldsymbol{P}- \\
\text { Value } \\
(0,012)\end{array}$} \\
\hline & \multicolumn{2}{|c|}{ Kasus } & \multicolumn{2}{|c|}{ Kontrol } & & & \\
\hline & (n) & $(\%)$ & (n) & $(\%)$ & $\mathrm{N}$ & $\%$ & OR \\
\hline Kurang & 12 & 37,5 & 22 & 68,8 & 34 & 53,1 & $(3,667)$ \\
\hline Baik & 20 & 62,5 & 10 & 31,2 & 30 & 46,9 & $95 \% \mathrm{CI}$ \\
\hline Total & 32 & 100 & 32 & 100 & 64 & 100 & $10,321)$ \\
\hline
\end{tabular}

Sumber : Data Primer, Diolah Agustus 2020

Berdasarkan tabel 13, dapat di ketahui bahwa dari 32 responden $(100 \%)$ pada kelompok kasus, terdapat 20 responden $(62,5 \%)$ yang memiliki 
pengetahuan baik dan terdapat 12 responden $(37,5 \%)$ yang memiliki pengetahuan kurang. Sedangkan kelompok kontrol terdapat $10(31,2 \%)$ yang memiliki pengetahuan baik dan terdapat 22 responden $(68,8 \%)$ yang memiliki tingkat pengetahuan kurang.

Hasil Analisis statistik dengan uji Chi-Square terkait tingkat pengetahuan ibu dengan kejadian kekurangan energ kronik (KEK) pada ibu hamil pada Confidence Interval (CI) 95\% di peroleh dari OR yakni 3.667 dengan Lower Limit (Batas Bawah) adalah angka pada kolom yang letaknya disebelah kiri yakni 1.303 dan Upper Limit (Batas atas) adalah angka pada kolom yang letaknya disebelah kanan yakni 10.321 Intreprestasi nilai Lower Limit dan Upper Limit tidak mencakup nilai satu maka Ho di tolak dan OR dinyatakan bermakna, sehingga dapat di nyatakan bahwa adanya hubungan antara tingkat pengetahuan ibu dengan kejadian kekurangan energi kronik sebanyak 3,6 kali lebih beresiko dengan tingkat pengetahuan kurang dibandingkan dengan ibu hamil yang memiliki tingkat pengetahuan baik.

Tabel 8. Analisis Faktor Risiko penyakit infeksi dengan Kekurangan energi kronik (KEK) Ibu hamil di Wilayah Keja Puskesmas Nambo Kota Kendari tahun 2020

\begin{tabular}{|c|c|c|c|c|c|c|c|}
\hline \multirow{3}{*}{$\begin{array}{l}\text { Penyakit } \\
\text { Infeksi }\end{array}$} & \multicolumn{4}{|c|}{ Kejadian KEK } & \multirow{2}{*}{\multicolumn{2}{|c|}{ Total }} & \multirow{2}{*}{$\begin{array}{c}\text { P-V alue } \\
(0,302)\end{array}$} \\
\hline & \multicolumn{2}{|c|}{ Kasus } & \multicolumn{2}{|c|}{ Kontrol } & & & \\
\hline & (n) & $(\%)$ & (n) & $(\%)$ & $\mathbf{N}$ & $\%$ & OR \\
\hline Ada & 3 & 9,4 & 1 & 3,1 & 4 & 6,2 & $(3,207)$ \\
\hline Tidak ada & 29 & 90,6 & 31 & 96,6 & 60 & 93,9 & $95 \% \mathrm{CI}$ \\
\hline Total & 32 & 100 & 32 & 100 & 64 & 100 & $32,604)$ \\
\hline
\end{tabular}

Sumber: Data Primer, Diolah Agustus 2020

Berdasarkan tabel 13, dapat diketahui bahwa dari 32 responden $(100 \%)$ pada kelompok kasus, terdapat 3 responden $(9,4 \%)$ yang memiliki penyakit infeksi dan terdapat 29 responden $(90,6 \%)$ yang tidak memiliki penyakit infeksi. Sedangkan pada kelompok kontrol, dari 32 responden $(100 \%)$ terdapat 1 responden $(3,1 \%)$ yang memiliki penyakit infeksi dan 31 responden $(96,6 \%)$ yang tidak memiliki penyakit infeksi.

Hasil analisis statistik dengan uji Chi Square terkait faktor risiko penyakit infeksi terhadap kejadian kekurangan energi kronik (KEK) pada Confidence Interval (CI) 95\% diperoleh nilai OR yakni 3,207 dengan Lower Limit (batas bawah) yakni 0.315 dan Upper Limit (batas atas) yakni 32.604 .Interpretasi nilai Lower Limit dan Upper Limit mencakup nilai satu, maka Ho diterima dan OR dinyatakan tidak bermakna. Dengan demikian penyakit infeksi bukan merupakan faktor risiko kejadian kekurangan energ kronik (KEK) pada ibu hamil di wilayah kerja Puskesmas Nambo Kota Kendari.

\section{PEMBAHASAN}

Faktor Risiko Pola Konsumsi Dengan Kejadian Kekurangan Energi Kronik (KEK) Ibu Hamil

Pola konsumsi adalah susunan jenis dan jumlah pangan yang di konsumsi seseorang atau kelompok.
Upaya mencapai status gizi masyarakat yang baik atau optimal di mulai dari penyediaan pangan yang cukup di peroleh melalui produksi pangan dalam negeri yaitu upaya pertanian dalam menghasilkan bahan makanan pokok, lauk pauk, sayur-sayuran dan buah-buahan. Pola konsumsi ini juga dapat mempengaruhi status kesehatan ibu, dimana pola konsumsi yang kurang baik dapat menimbulkan suatu gangguan kesehatan atau penyakit pada ibu. ${ }^{6}$

Berdasarkan hasil penelitian terdapat hubungan antara pola konsumsi dengan kejadian kekurangan energi kronik (KEK), dapat diketahui bahwa terdapat 64 responden $(! 00 \%)$ ibu hamil yang memiliki pola konsumsi kurang dari keseluruhan adalah 39 responden $(60,9)$, sedangkan ibu hamil yang memiliki pola konsumsi baik 25 responden (39,1\%), dengan hasil analisis uji chi-square dapat diperoleh nilai Odd Ratio yakni 3,4 pola konsumsi kurang lebih beresiko di banding dengan pola konsumsi yang baik di wilayah kerja Puskesmas Nambo.

Hasil penelitian ini sejalan dengan penelitian yang dilakukan oleh Febriyeni (2017) dengan judul faktor-faktor yang berhubungan dengan kejadian kurang energi kronik (KEK) pada ibu hamil Puskesmas Banja Laweh. Analisis bivariate diketahui ada hubungan pola makan $(p=0,019)$ dengan kejadian KEK pada ibu hamil. Hal ini sejalan dengan penelitian yang dilakukan oleh Rahayu (2019) yang menunjukkan bahwa terdapat hubungan antara tingkat pola konsumsi dengan kejadian kekurangan energi kronik pada ibu hamil di Puskesmas Grogol Kediri dengan hasil analisis chi-square didapatkan nilai $p$-value $=0,001$. Penelitian Fitrianingsih (2014) yang menunjukkan bahwa terdapat hubungan antara pola konsumsi dengan kekurangan energi kronik pada ibu hamil di Puskesmas Tompobulu Kabupaten Gowa dengan hasil analisis chi-square didapatkan nilai $p$ value $=0,02$. Juga penelitian yang dilakukan oleh Wijayanti (2019) menunjukkan bahwa terdapat hubungan antara pola konsumsi dengan kekurangan energi kronik pada ibu hamil di Puskesmas Gabus I Kabupaten Pati, dengan hasil analisis chi-square didapatkan nilai $p$-value $=0,001{ }^{7}$

Menurut asumsi penelitian dapat diketahui bahwa data yang diperoleh responden sebagian besar ibu hamil dengan pola konsumsinya kurang seeperti masih ada ibu hamil yang kurang mengkonsumsi sayuran salah satunya bayam, manfaat bayam untuk ibu hamil sangat kaya untk vitamin A,C, E, kalium dan zat besi. Hal ini dikarenakan ibu hamil kurang memperhatikan pemenuhan makanannya sendiri yang akan berdampak pada keadaan gizi ibu hamil. Ibu yang pola konsumsinya kurang dapat diindikasikan bahwa ibu tidak tercukupi kebutuhan nutrisinya selama hamil sehingga memiliki peluang status gizi kurang atau dalam hal ini kekurangan energi kronik. Hal ini dapat diindikasikan bahwa mayoritas ibu hamil memiliki kebiasaan makan yang sama seperti sebelum hamil, padahal kebutuhan konsumsi disaat hamil akan 3 kali lipat lebih banyak dari sebelumnya.

Hal ini diketahui bahwa asupan gizi kurang akan menyebabkan kurangnya protein, karbohidrat, zat besi dan lemak selama kehamilan yang dapat menyebabkan 
ibu yang mengalami KEK. Sedangkan hasil penelitian juga masih dijumpai adanya ibu yang pola konsumsinya sesuai tetapi mengalami KEK dengan kondisi yang kurus. Ini juga diketahui bahwa masih banyak ibu hamil yang memiliki pekerjaan sehari-harinya baik yang dilakukan di dalam rumah tangga maupun dilakukan di luar rumah seperti ada ibu ada ibu yang bertani, berdagang. Sehingga ibu hamil yang tidak bekerja juga tetap membantu pekerjaan suaminya, sehingga beban kerja ibu hamil yang tidak bekerja juga tetap dilakukan ibu hamil akan mempengaruhi pemenuhan kebutuhan gizi sehari-hari.

Ibu hamil membutuhkan zat gizi yang lebih banyak dibandingkan sebelum hamil.hal ini disebabkan karena selain untuk ibu hamil zat gizi dibutuhkan bagi janin yang dikandung, janin tumbuh dengan mengambil zat-zat gizi dari makanan yang dikonsumsi oleh ibu dan dari simpanan zat gizi yang berada dalam tubuh ibu. Khusus ibu hamil yang mengalami KEK perlu dilakukan penanganan intensif melalui intervensi gizi secara spesifik dan sensitif secara berkelanjutan. Dalam penelitian ini juga ditemukan beberapa responden yang memiliki pola konsumsi kurang namun tidak mengalami KEK. Namun apabila ibu hamil tidak memperbaiki pola konsumsinya dan yang dilakukan ibu hamil tersebut berlangsung lama maka berpeluang mengalami kekurangan energi kronis nantinya.

Faktor Risiko Pantang Makan Dengan Kejadian Kekurangan Energi Kronik (KEK) Ibu Hamil

Menurut Sulistyoningsih (2011) pantangan makan merupakan salah satu pola konsumsi yang dapat mempengaruhi asupan makan pada ibu hamil. Makanan yang dikonsumsi manusia digunakan untuk mempertahankan kelangsungan hidupnya, tetapi ada yang beranggapan bahwa terdapat satu atau beberapa makanan yang berbahaya apabila orang memakannya. Sehingga menimbulkan perilaku seseorang yang tidak mengonsumsi makanan tertentu. Hal tersebutlah yang disebut sebagai pantang makan.Faktor yang mempengaruhi pantang makan yaitu faktor social budaya dan kepercayaan, dalam pantangan agama, tahayul, dan kepercayaan tentang kesehatan, terdapat bahan makanan bergizi yang tidak boleh dimakan. Hal tersebut dapat menyebabkan ibu dengan pantangan makanan tertentu memiliki risiko untuk terjadi KEK (Rukmono, 2019). ${ }^{8}$

Berdasarkan hasil penelitian terdapat hubungan antara pantang makan dengan kejadian kekurangan energi kronik (KEK), dapat diketahui bahwa terdapat 64 responden $(! 00 \%)$ ibu hamil yang memiliki pantang makan ada dari keseluruhan adalah 36 responden $(56,2)$, sedangkan ibu hamil yang tidak memiliki pantang makan 28 responden (43,8\%), dengan hasil analisis uji chi-square dapat diperoleh nilai Odd Ratio yakni 2,8 dengan ibu hamil yang memiliki pantang makan ada lebih beresiko di banding dengan ibu hamil yang tidak memiliki pantang makan di wilayah kerja Puskesmas Nambo.

Berbeda dengan penelitian yang dilakukan oleh Oktriyani, dkk (2014) yang menunjukkan bahwa tidak terdapat hubungan yang bermakna antara pantangan makan dengan kekurangan energi kronik pada ibu hamil di Kecamatan Sedayu, Bantu, Yogyakarta dengan hasil analisis chi-square didapatkan nilai p-value $=0,44$. Penelitian Amirudin, dkk (2011) yang menunjukkan bahwa tidak terdapat hubungan yang bermakna antara pantangan makan dengan kejadian kekurangan energi kronik pada ibu hamil di Kota Pekalongan dengan hasil analisis chi-square didapatkan nilai $p$-value $=1,0$. Penelitian Ardini (2018) menunjukkan bahwa tidak terdapat hubungan antara pantangan makan dengan kejadian kekurangan energi kronik pada ibu hamil di Puskesmas Payung Sekaki Pekanbaru dengan hasil analisis chi-square didapatkan nilai $p$-value $=0,168 .{ }^{9}$

Berdasarkan hasil penelitian yang telah dilakukan ibu hamil yang memiliki pantang makan ada di karenakan mereka masih memiliki kepercayaan memantang makan terhadap makanan yang di konsumsi dengan alasan apabila di konsumsi pada saat hamil akan mengakibat kelainan pada bayi yang di lahirkan sehingga asupan makanan pada ibu hamil menjadi kurang. Adapun alasan dibalik adanya pantangan makan berdasarkan wawancara dengan responden terbagi menjadi dua penyebab, ada yang disebabkan karena mitos yang dipercayai seperti meminum es saat hamil dapat menyebabkan bayi memiliki berat lahir yang berlebih dan menyulitkan kelahiran. Ada pula karena alasan kesehatan seperti ibu yang mengalami iritasi pada lambung disarankan untuk tidak mengkonsumsi cabe. Ibu hamil yang memiliki alergi terhadap telur dan makanan laut. Tetapi dalam hal ini responden juga masih banyak yang masih mempercayai adanya pantang makan saat kehamilan.

Menurut penelitian Siti Nurul Huda dkk, (2019) alasan ibu berpantang minum es saat hamil karena dapat menyebabkan berat badan bayi menjadi besar dapat mempersulit pada saat melahirkan. Kebutuhan akan cairan sangat penting untuk menjaga kesehatan ibu hamil dan janin dalam kandungan, terlepas dari meminum es atau air hangat. Air es yang membuat bayi menjadi besar adalah apabila dicampur dengan bahan makanan yang mengandung glukosa tinggi sepertigula atau sirup, karena makanan atau minuman dengan glukosa tinggi secara berlebihan bias membuat janin menjadi berukuran besar. Adapula dengan mengkonsumsi cabe bahwa akan menyebabkan ibu hamil membehayakan perkembangan janin. Cabe dalam segi kesehatan memiliki kandungan vitamin $C$ yang sangat tinggi. Selain itu cabe atau cabai juga memiliki kandungan vitamin $\mathrm{A}$, vitamin $\mathrm{B}$, dan vitamin $\mathrm{E}$, serta memiliki kandungan $\mathrm{m}^{10}$

Seringkali ditemukan adanya pantang makan bagi wanita hamil terhadap beberapa jenis makanan tertentu yang jika dilihat dari nilai gizi, bahan makanan tersebut juga mungkin saja dibutuhkan oleh ibu. Secara umum, tidak ada pantang makan bagi ibu hamil selama ibu tidak mengalami komplikasi ataupun mengalami penyakit lain. Ibu hamil boleh mengkonsumsi makanan yang diinginkan dengan jumlah yang tidak berlebihan. Adanya pantangan seperti itu akan menghambat pemenuhan kebutuhan gizi ibu yang akhirnya berbahaya bagi kesehatan ibu serta pertumbuhan dan perkembangan janin, sehibgga perlu penjelasan kepada ibu tentang manfaat makanan serta bahaya pantangan. 
Faktor Risiko Pengetahuan Ibu Dengan Kejadian Kekurangan Energi Kronik (KEK) Ibu Hamil

Pengetahuan ibu hamil yaitu pengetahuan ibu hamil tentang adanya kejadian kekurangan energi kronik (KEK), dimana pengetahuan sangat penting bagi siapapun termasud ibu hamil. Menurut Notoamodjo (2010), pengetahuan dating dari pengalaman, juga biasa didapat dari informasi yang disampaikan oleh guru, orang tua, buku, dan surat kabar. Pengetahuan ini berperan penting untuk terbentuknya tindakan seseorang.

Berdasarkan hasil penelitian terdapat hubungan antara pengetahuan ibu dengan kejadian kekurangan energi kronik (KEK), dapat diketahui bahwa terdapat 64 responden $(! 00 \%)$ ibu hamil yang memiliki pengetahuan ibu kurang dari keseluruhan adalah 34 responden $(53,1)$, sedangkan ibu hamil yang memiliki pengetahuan ibu baik 30 responden (46,9\%), dengan hasil analisis uji chi-square dapat diperoleh nilai Odd Ratio yakni 3,6 dengan pengetahuan ibu kurang lebih beresiko di banding dengan pengetahuan ibu baik di wilayah kerja Puskesmas Nambo.

Berdasarkan penelitian yang dilakukan lebih banyak ibu hamil yang pengetahuannya masih kurang seperti ibu hamil perlu mengkonsumsi tablet penambah darah bahwa ini penting karena untuk membantu tubuh ibu memproduksi lebih banyak hemoglobin selama kehamilan. Di sisi lain, ibu hamil juga butuh tablet tambah darah guna memenuhi kebutuhan zat besi untuk mendukung pertumbuhan bayi dan plasenta di dalam Rahim terutama trimester 2 dan trimester 3 kehamilan. Oleh karena itu responden menganggap bahwa pengetahuan mereka sudah cukup, tetapi malah sebaliknya. Kemampuan ibu hamil untuk memahami pentingnya mendapatkan informasi melalui media apapun seperti melalui smart phone, pengalaman, atau cerita itu sangat penting bagi ibu hamil. Ibu hamil juga kurang melakukan kunjungan puskesmas atau posyandu untuk melakukan pemeriksaan kehamilannya. Maka dari itu ibu hamil juga termaksud kurang memiliki pengetahuan tentang gizi sehingga mempengaruhi perilaku dalam memilih makanan untuk kebutuhan nutrisinya.menurut Surasih (2005), kurangnya pengetahuan ibu hamil sangat berguna bagi sang ibu sendiri, karena itu kebutuhan energi zat gizi lainnya sangat meningkat selama kehamilan. Ibu dengan pengetahuan baik mengerti dengan benar betapa diperlukannya peningkatan energi dan zat gizi yang cukup akan membuat janin tumbuh dan sempurna. ${ }^{11}$

Hal ini tidak sejalan dengan penelitian yang di lakukan oleh setyorini,dkk (2017), hasil analisa uji satistik dengan menggunakan chi-square diperoleh nilai $p$ value $0,124(\mathrm{p}>0,05)$ hal ini berarti Ho diterima yang menunjukan tidak terdapat hubungan signifikan antara pengetahuan dengan kejadian kekurangan energi kronik (KEK) pada ibu hamil di puskesmas pringapus kabupaten semarang. Penelitian yang di lakukan oleh prayitno (2019), hasil analisis uji satistik dengan menggunakan chi-square di peroleh nilai p-value 0,115 (p $>0,05)$ hal ini berarti Ho diterima yang menunjukan tidak terdapat hubungan signifikan antara pengetahuan dengan kejadian kekurangan energi kronik (KEK) pada ibu hamil di kota Bandar lampung. Penelitian yang dilakukan oleh Adriani dan Wirjatmadi (2012) yang menunjukkan bahwa tidak terdapat hubungan yang signifikan antara tingkat pengetahuan dengan kejadian kekurangan energi kronik (KEK) pada ibu hamil di wilayah kerja puskesmas Ipuh kabupaten Muko-Muko ${ }^{12}$

Faktor Risiko Penyakit Infeksi Dengan Kejadian Kekurangan Energi Kronik (KEK) Ibu Hamil

Penyakit infeksi dapat bertindak sebagai pemula terjadinya kurang gizi sebagai akibat menurunnya nafsu makan, adanya gangguan penyerapan dalam saluran pencernaan atau peningkatan kebutuhan zat gizi oleh adanya penyakit. Kaitan penyakit infeksi dengan keadaan gizi kurang merupakan hubungan timbal balik, yaitu hubyngan sebab akibat. Penyakit infeksi dapat memperburuk keadaan gizi dan keadaan gizi yang jelek dapat mempermudah penyakit infeksi. ${ }^{13}$

Dapat diketahui bahwa sampel terdiri 64 responden $(100 \%)$ pada kelompok kasus, terdapat 3 responden $(9,4 \%)$ yang memiliki penyakit infeksi ada dan terdapat 29 responden (90,6\%) yang tidak memiliki penyakit infeksi. Sedangkan pada kelompok kontrol, dari 32 responden $(100 \%)$ terdapat 1 responden $(3,1 \%)$ yang memiliki penyakit infeksi ada dan 31 responden $(96,6 \%)$ yang tidak memiliki penyakit infeksi.

Hasil penelitian ini menunjukkan bahwa penyakit infeksi bukan merupakan faktor risiko kejadian kekurangan energi kronik (KEK) ibu hamil di wilayah kerja puskesmas nambo kota kendari dibuktikan dengan hasil analisis bivariate bahwa faktor risiko penyakit infeksi dengan nilai OR = 3,207 (95\%CI;0,315-32,604). Secara statistik menunjukkan tidak ada hubunganyang bermakna antara faktor risiko penyakit infeksi dengna kejadian kekurangan energi kronik (KEK) ibu hamil di wilayah kerja Puskesmas Nambo Kota Kendari.

Dalam penelitian ini hasil wawancara responden terdapat 4 responden $(6,2 \%)$ yang terdapat faktor risiko penyakit infeksi terkait dengan gizi yang diderita ibu hamil yaitu diare yang dilihat dari gejala-gejala penyakit yang responden rasakan yaitu dengan kurangnya nafsu makan sehingga mengurangi asupan gizi, dan diare juga dapat mengurangi daya serap usus terhadap sari makanan. Dalam keadaan infeksi, kebutuhan sari makanan yang mengalami diare akan meningkat, sehingga setiap serangan diare akan menyebabkan kekurangan gizi. Beberapa gejala dan tanda diare antara lain : berak cair atau lembek dan sering gejala khas diare, muntah, demam, dan gejala dehidrasi (Widoyono, 2008). ${ }^{14}$ Infeksi mempengaruhi status protein, misalnya infeksi ringan sekalipun akan mengakibatkan bertambahnya kehilangan nitrogen melalui urin. Infeksi juga membantu terjadinya kekurangan protein karena menyebabkan berkurangnya nafsu makan (Sastroamidjo, 1980). ${ }^{15}$

Penelitian ini sejalan dengan penelitian Kartini (2017) yang menyatakan bahwa tidak ada hubungan antara penyakit infeksi dengan kejadian kekurangan energi kronik (KEK), penelitian tersebut menunjukkan bahwa terjadi kenaikan kekurangan energi kronik (KEK) berisiko mengalami komplikasi baik dalam kehamilan maupun dalam persalinannya sehingga perlu dilakukan perbaikan gizi pada ibu hamil. 
Penyakit infeksi dapat bertindak sebagai pemula terjadinya kurang gizi sebagai akibat menurunnya nafsu makan, adanya gangguan penyerapan dalam saluran pencernaan atau peningkatan kebutuhan zat oleh adanya penyakit. Kaitan penyakit infeksi dengan keadaan gizi kurang merupakan timbal balik, yaitu hubungan sebab akibat. Penyakit infeksi dapat memperburuk keadaan gizi dan keadaan gizi yang jelek dapat mempermudah infeksi (Supariasa, 2010). ${ }^{16}$

\section{SIMPULAN}

1. Pola konsumsi merupakan faktor risiko dengan kejadian kekurangan energi kronik (KEK) Ibu hamil di wilayah kerja Puskesmas Nambo Kota Kendari yang dimana dapat diperoleh nilai OR 3,4 kali lebih berisiko yang pola konsumsinya kurang dibanding dengan pola konsumsinya yang baik.

2. Pantang makan merupakan faktor risiko dengann kejadian kekurangan energi kronik (KEK) ibu hamil diwilayah kerja Puskesmas Nmabo Kota Kendari yang dimana dapat diperoleh nilai OR 2,8 kali lebih beresiko yang memiliki pantang makan ada dibanding dengan ibu hamil yang tidak memiliki pantang makan.

3. Pengetahuan Ibu merupakan faktor risiko dengan kejadian kekurangan energi kronik (KEK) ibu hamil di wilayah kerja Puskesmas Nambo Kota Kendari.yang dimana dapat diperoleh nilai OR 3,6 kali lebih beresiko dengan tingkat pengetahuan kurang dibandingkan dengan ibu hamil yang memiliki tingkat pengetahuan baik.

4. Penyakit infeksi bukan merupakan faktor risiko dengan kejadian kekurangan energi kronik (KEK) ibu hamil di wilayah Kerja Puskesmas Nmabo Kota Kendari yang dimana nilai OR dinyatakan tidak bermakna.

\section{SARAN}

1. Peneliti berharap agar hasil penelitian ini dapat menjadi sumber informasi tentang adanya faktor risiko pola konsumsi, pantang makan, pengetahuan ibu, penyakit infeksi terhadap kejadian kekurangan energi kronik pada ibu hamil di wilayah kerja Puskesmas Nambo Kota Kendari.

2. Peneliti juga berharap agar ibu hamil pengunjung yang telah memiliki atau mendapatkan informasi dapat meningkatkan pemahaman ibu tentang dampak kekurangan energi kronik (KEK) dan pentingnya mengatur pola konsumsi dengan mengkonsumsi makanan yang cukup untuk kebutuhannya saat hamil, pentingnya mengetahui adanya pantang makan itu mitos atau fakta, pentingnya membangun pengetahuan ibu, dan mengetahui adanya baik buruknya makanan untuk ibu hamil, dan juga terjauh dari dari adanya penyakit infeksi agar dapat menjaga kesehatannya saat sedang hamil

3. Peneliti berharap agar adanya hasil penelitian ini dapat di jadikan sebagai sumber informasi untuk peneelitian selanjutnya yang akan melakukan penelitian dengan topic serupa namun menggunakan desain yang berbeda serta menggunakan variable yang lebih bervariasi meskipun demikian masih perlu diteliti dalam lagi dengan jumlah sampel yang lebih banyak dan analisis yang berbeda pula.

\section{DAFTAR PUSTAKA}

1. Demsa, Simbolon. 2018. Pencegahan dan Penanggulangan Kurang Energi Kronik (KEK) dan Anemia Pada Ibu Hamil. Yogyakarta : Deeepublish

2. World Health Organization (WHO). 2016. “Maternal Mortality." Artikel diakses 10 November 2019darihttp://www.who.int/mediacentre/factsheet /fs348/en/

3. Fatimah, dkk. Pola Konsumsi Dan Kadar Hemoglobin Pada Ibu Hamil Di Kabupaten Maros, Sulawesi Selatan. 2019;15(1):31-6.

4. Kemenkes RI. (2018) Riset Kesehatan Dasar. Jakarta: Bakti Husada.

5. Sediaoetama. (2014). Ilmu Gizi Untuk. Mahasiswa dan Profesi Jilid II. Jakarta: Dian Rakyat.

6. Dinas Kesehatan Provinsi Sulawesi Tenggara. (2018). Profil Kesehatan Provinsi Sulawesi Tenggara 2018. Kendari: Dinas Kesehatan Provinsi Sulawesi Tenggara.

7. Profil Kesehatan Kota Kendari Tabun 2019. Kendari: Dinas Kesehatan Kota Kendari.

8. Sulistyoningsih 2011. Gizi Untuk Kesehatan Ibu Dan Anak. Yogyakarta: Graha Ilmu.

9. Notoatmodjo, S. 2010. Metodologi Penelitian Kesehatan. Jakarta: Rineka Cipta

10. Surasih, H. (2014). Faktor-Faktor Yang Berhubungan Dengan Kekurangan Energi kronik (KEK) Pada Ibu Hamil di Kecamatan Kamoning Dan Tambelang Kabupaten Sampang Jawa Timur. Naskah Publikas. Semarang: IKM Universitas Negeri Semarang.

11. Supariasa, I., (2014) Penilaian Status Gizi. Jakarta: EGC

12. Suryaningsih, dkk. 2016. Hubungan Antara Tingkat Pengetahuan Ibu Hamil Tentang Kekurangan Energi Kronik Dengan Ukuran Lingkar Lengan Atas Di Puskesmas Depok III Sleman. Jurnal Permata Indonesia. (Volume 8 (1), 8-13)

13. Sigit, R.A., (2015) Hubungan Antara Pengetahuan Tentang Gizi Dan Konsusmsi Protein Dengan Kejadian KEK. Jurnal Kebidanan. Vol. 3.

14. Waryana. 2010. Gizi Reproduksi. Yogyakarta: Pustaka Rihama

15. Prawirohardjo, S. 2012. Ilmu Kebidanan. Jakarta: Yayasan Bina Pustaka Sarwono Prawirohardjo

16. Putri, Alvina. 2015. Faktor Yang Berbubungan Dengan Pola Konsumsi Makan Dengan Kejadian Kek Pada Ibu Hamil Di Puskesmas Bandar Lampung. Skripsi. Universitas Islam Negeri Syarif Hidayatullah Jakarta.

17. Rahayu, dkk. 2019. Pola Makan Dan Pendapatan Keluarga Dengan Kejadian Kekurangan Energi Kronik Pada Ibu Hamil Trimester II. Holistik Jurnal Kesehatan. Vol.13. No.1 